
A Physiographic and Ecological Study of the Lake Eagle (Lake Wimona) Region, Indiana

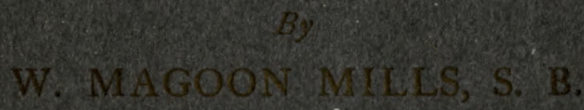

The Untversity of chlegiga

CHICAGO

This Quaprangcr Ptags

1902 



\title{
A Physiographic and Ecological Study of the Lake Eagle \\ (Lake Winona) Region, Indiana
}

\author{
By \\ W. MAGOON MILLS, S. B. \\ The University of Chicago
}
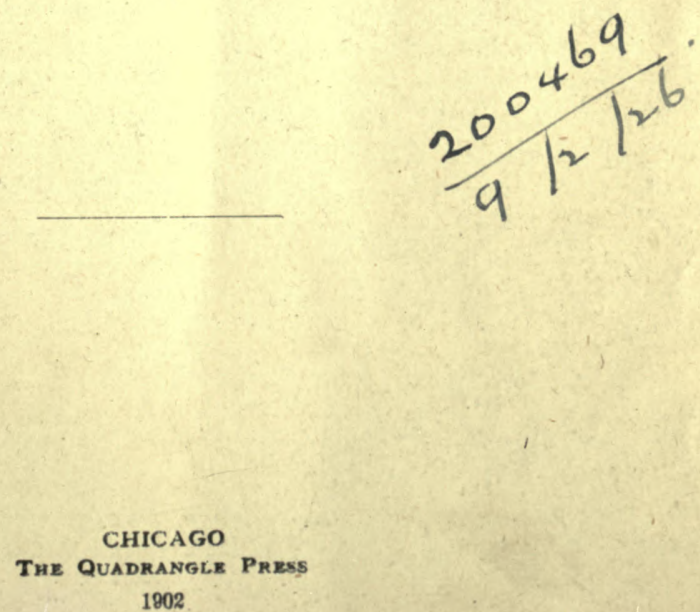

1902 


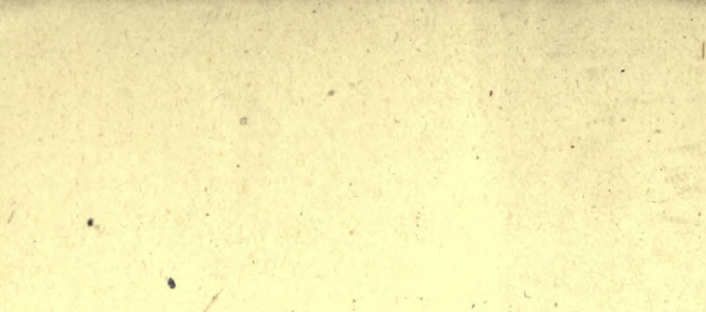

49.120 


\section{PREFATORY NOTE}

The following report is the result of a summer's work done in connection with the Biological Station of the Indiana University at Lake Winona, Ind. The locality is a hydrographic basin representing a physiographic and ecological unit, and for that reason is one well adapted for a study. During the first part of the summer, the class in ecology under Dr. H. C. Cowles, of the University of Chicago, had for their work the tracing of the natural history of the locality along ecological lines, and also to show what was going on at that time in the same line. It was while this work was in progress that evidences were discovered in the physiographic history which seemed to the writer extremely interesting. Accordingly, the physiography was incorporated with the ecology in the report.

Return is here made for the co-operation of the other members of the class: Miss Belle Highlands, of Madison, Ind., Miss Lucy Youse, of Terre Haute, Ind,, and Mr. Collett, of Zenia, Ohio. To his instructor, Dr. Cowles, the author feels deeply indebted, not only for aid in the present effort, but for kindly guidance and suggestions which have characterized their class associations for the past few years. No one has done more to impart courage to the novice or to lift the be. ginner toward professional work than he.

Chicago, Ill., November 15, 1901 . 



\section{$\because$}

A

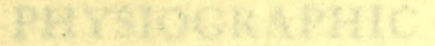 STLDY OF}

$$
\text { Whono) }
$$

Ragte bake or

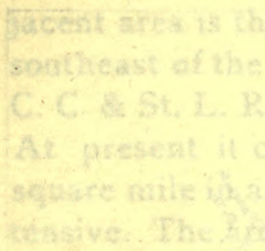

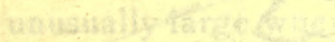

futucry stream 9 :

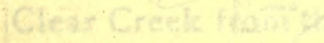

xiog is

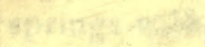

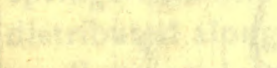

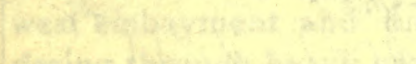

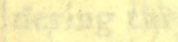

the Riv?

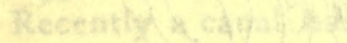

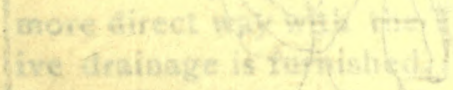

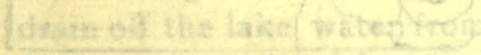

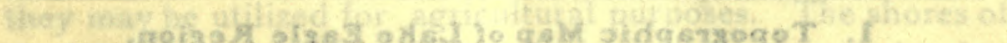

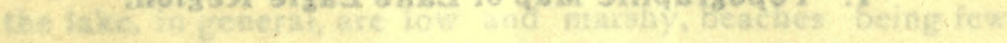

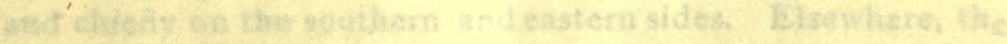

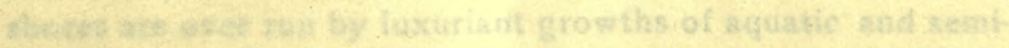

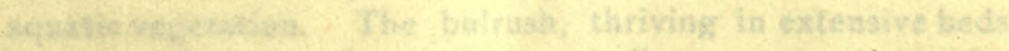

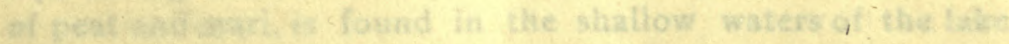

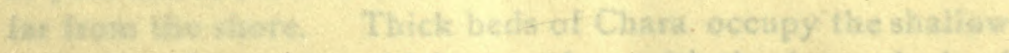

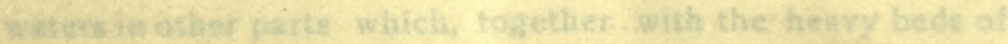
water Hither (Nymphaea) and pond litliea (Nuphat) are mapid ly rectainatag the lakebotion. 


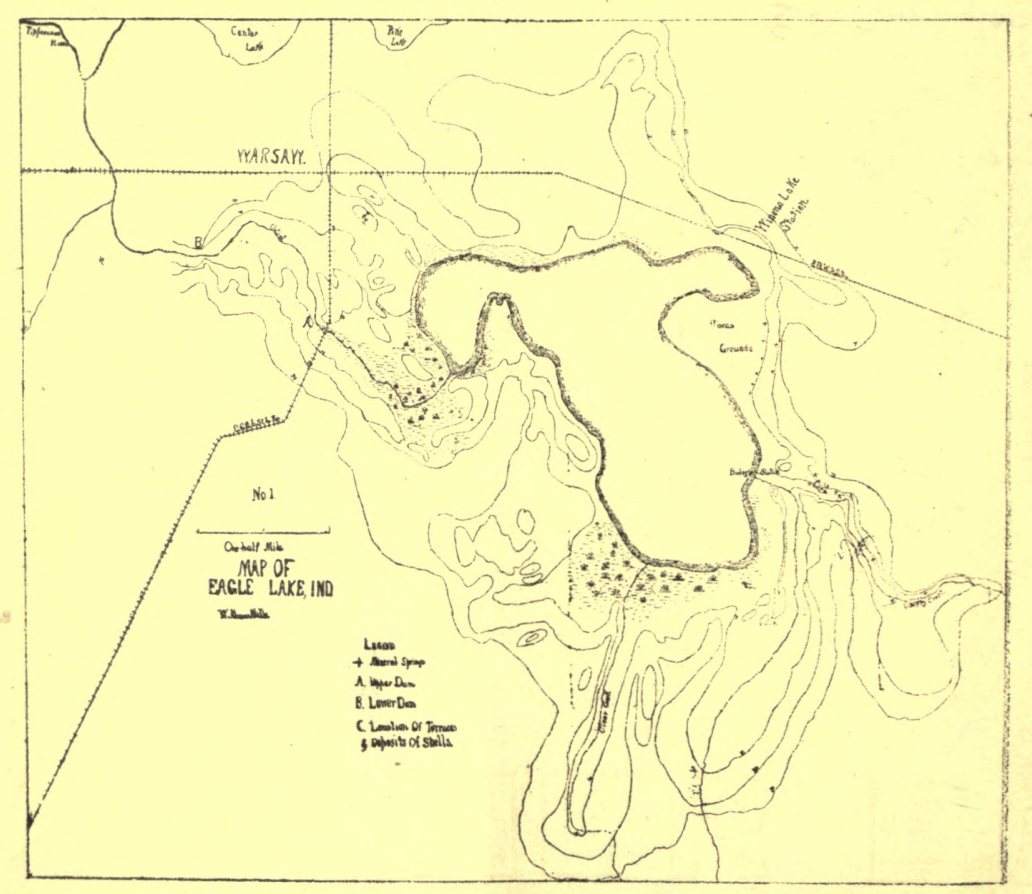

1. Topographic Map of Lake Eagle Region. 


\section{A PHYSIOGRAPHIC AND ECOLOGICAL STUDY OF THE LAKE EAGLE (Lake Winona) REGION, INDIANA}

Eagle Lake or Winona Lake, which, together with the adjacent area is the subject of this paper, is located immediately southeast of the junction of the P. Ft. W. \& C. Ry. and the C. C. C. \& St. L. Ry., in the northern part of Kosciusco Co. Ind. At present it consists of one main body of waterabout one square mile in area although formerly it was much more extensive. The area drained into the lake or "catchment basin" is unusually large when compared with the lake body. The tributary streams are two; Cherry Creek from the southeast and Clear Creek from the south. The amount of inflow from these two streams is quite insignificant when compared with that supplied by the numerous springs about the lake. These springs with one or two exceptions, are more or less regularly distributed along the eastern shore of the lake. The outlet is a small stream leaving the lake at the southern end of the northwest embayment and finds its way, after a sluggishly meandering through heavy growths of semi-aquatic vegetation, to the Tippecanoe River, about a mile west of Warsaw.

Recently a canal has been dug connecting the lake in a more direct way with the Tippecanoe, by which a more effective drainage is furnished. By this means it is intended to drain off the lake water from all the low lying lands so that they may be utilized for agricultural purposes. The shores of the lake, in general, are low and marshy, beaches being few and chiefly on the southern and eastern sides. Elsewhere, the shores are over run by luxuriant growths of aquatic and semiaquatic vegetation. The bulrush, thriving in extensive beds of peat and marl, is found in the shallow waters of the lake far from the shore. Thick beds of Chara occupy the shallow waters in other parts which, together with the heavy beds of water lillies (Nymphaea) and pond lillies (Nuphar) are rapidly reclaiming the lake bottom. 
Back from the lake there are elevations of some magnitude and fairly continuous. These are especially developed upon the eastern side, where they frequently rise to heights exceeding forty (40) feet. It is from this region that the lake derives the major part of its water. The lake itself is not deep and yet its depth when compared to that of inland lakes in general, is somewhat strikıng. Less than a mile in width for most of its length, it has an extreme depth of eighty-one (81) feet. This lake is typical of the glacial lakes of northern Indiana, all of them having bottoms rather deeper than the elevations of their immediate neighborhood. While the area here is not the "kettle and knob" topography perfect, such as exists at Valparaiso, yet it closely approaches that, the elevations and depressions being formed by the same agencies and largely under the same circumstances. As compared with these lakes, both those in the western states and those formed by glacial agencies in Wisconsin and Michigan are extremely shallow. The majority of the Nevada and Utah lakes, though of great area, average but a few feet in depth.

\section{THE TOPOGRAPHY}

Lake Eagle owes its origin to glacial influences. When the ice advance known as the Erie lobe moved southward and westward, it came in contact laterally with that ice advance from the north known as the Saginaw lobe. The median moraine, made up of long well marked ridges, is the region under discussion and about to be described. The general direction of this moraine is south 35 degrees west. All the glacial phenomena, once so powerful in forming the surface here, may still be approximately traced by their influences. The region is covered with a very thick mantle of drift, not only the thickest in the state, but much thicker than has been found in the states to the north. At Kendallville, Ind., a few miles to the north, but yet on the summit of the same moraine, the drift measures 485 feet in thickness. From this point south the thickness varies, being 245 feet at Eagle Lake, while at Wabash, 25 miles further south, it thins out to practically nothing. At this point the underlying rock comes to the surface. This moraine, in which Eagle Lake is located is one of the six eliptically-shaped moraines which at present round the 


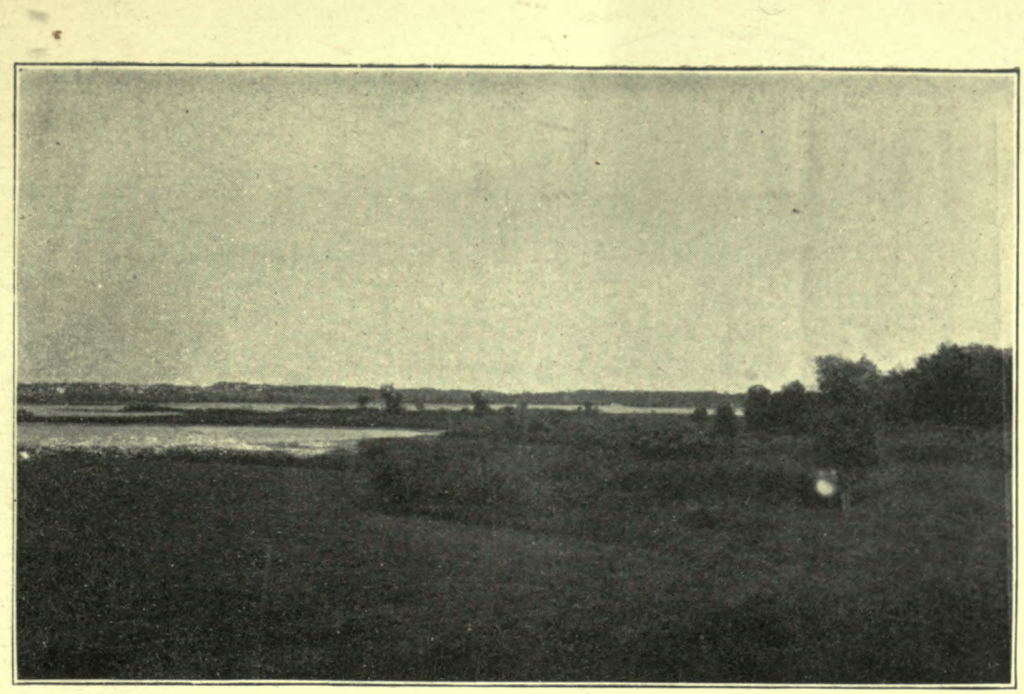

FIG. I. A view across the lake from near the outlet. Evidences of the rapid recession of the lake waters are plentiful. Most of the long tongues of rising land are largely beds of Chara and other water plants, Zones of white and yellow water lillies, cattails and sedges are seen near the water while further to the right mones of willow, Carolina rose and osier dogwood merge with the more mesophytic of the forest trees. On to the right is the regulation upland forest. Here is an example of swamp evolution.

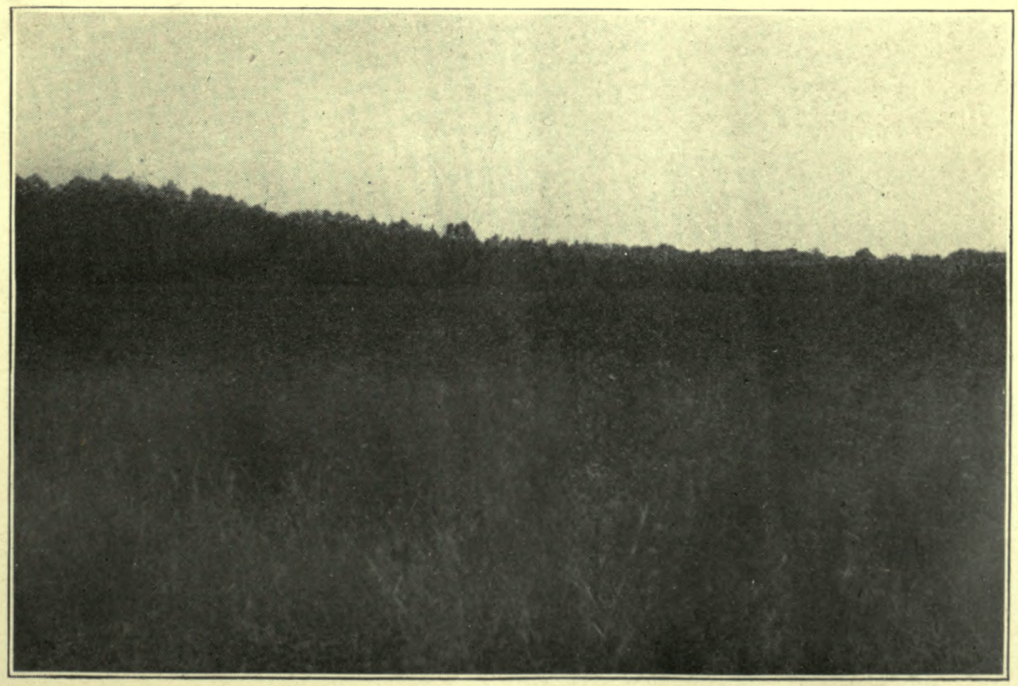

Fig. 2. Swamp meadow recovered naturally from the lake and on its soutbern edge. The forest in the upland back is an oak-hickory one. White oaks occupy the lower part of the slope, the black oaks the higher parts. If left alone, the meadow would become forested. The outer rim of trees are of the mesophytic order, their seedlings being annually destroyed by the mower. Ash. walnut, and swamp maple predominate near the meadow, 


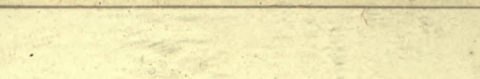




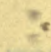

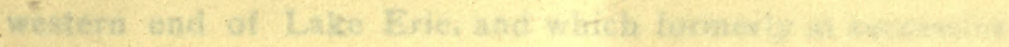

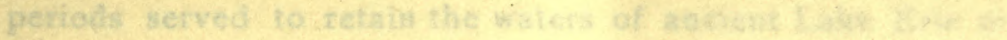

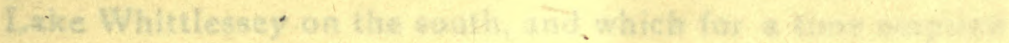

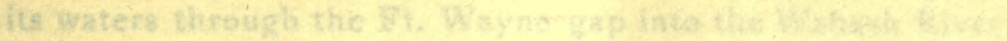

The drift of the englon is thit regulation olst

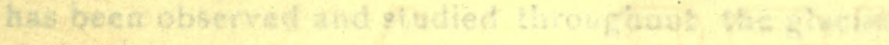

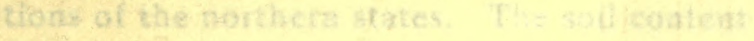
up of satwi and gravel with a dak. The magand of clay or spars herat an extretioly sma

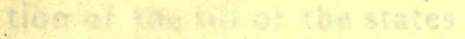

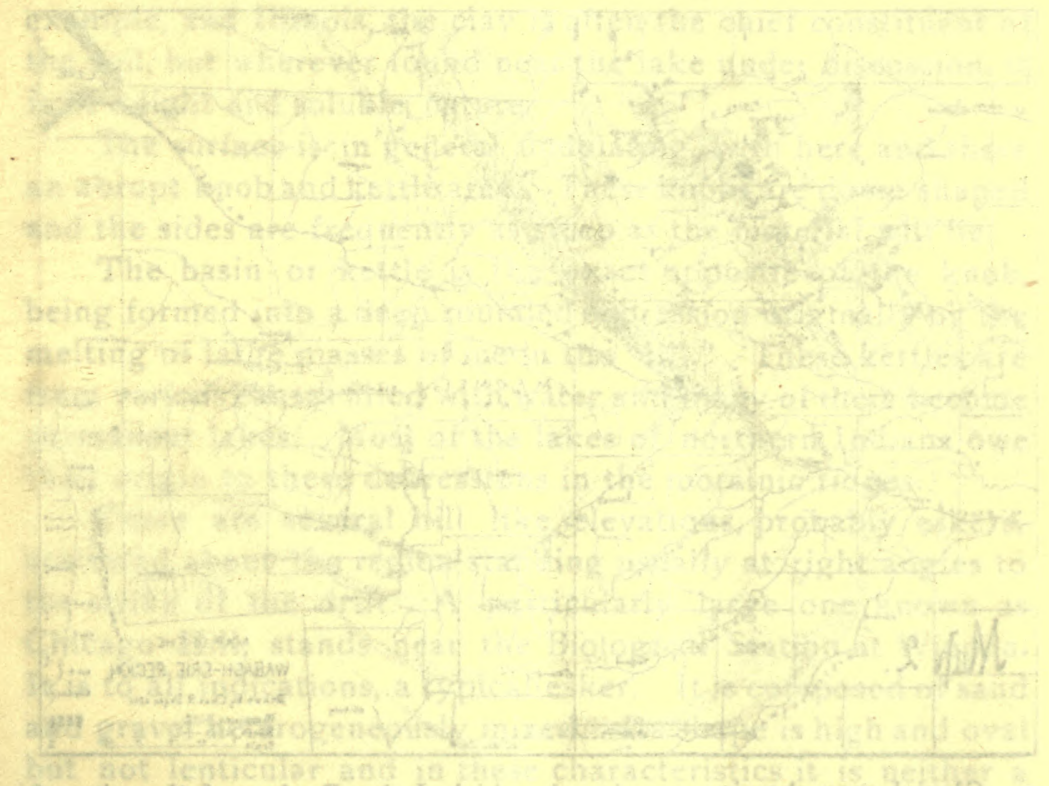

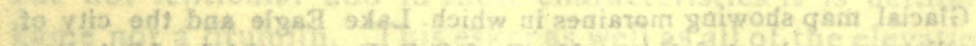

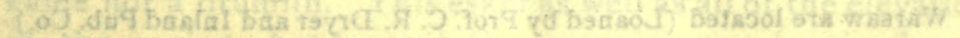
wot she region, was a we wethas wec, -clikg to conditions. An a

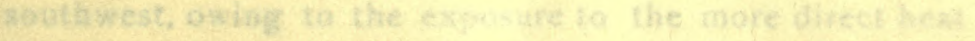

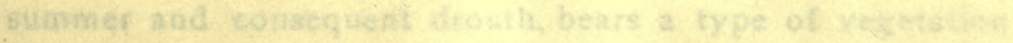

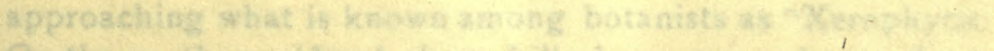

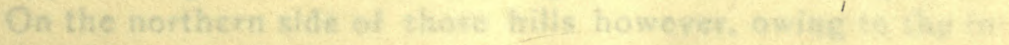

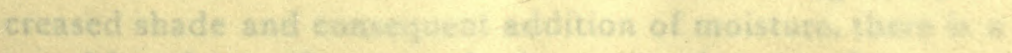

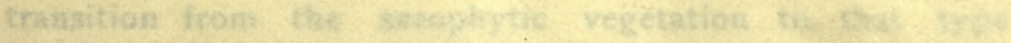

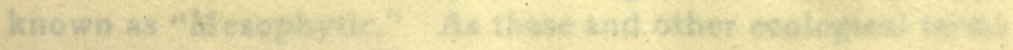




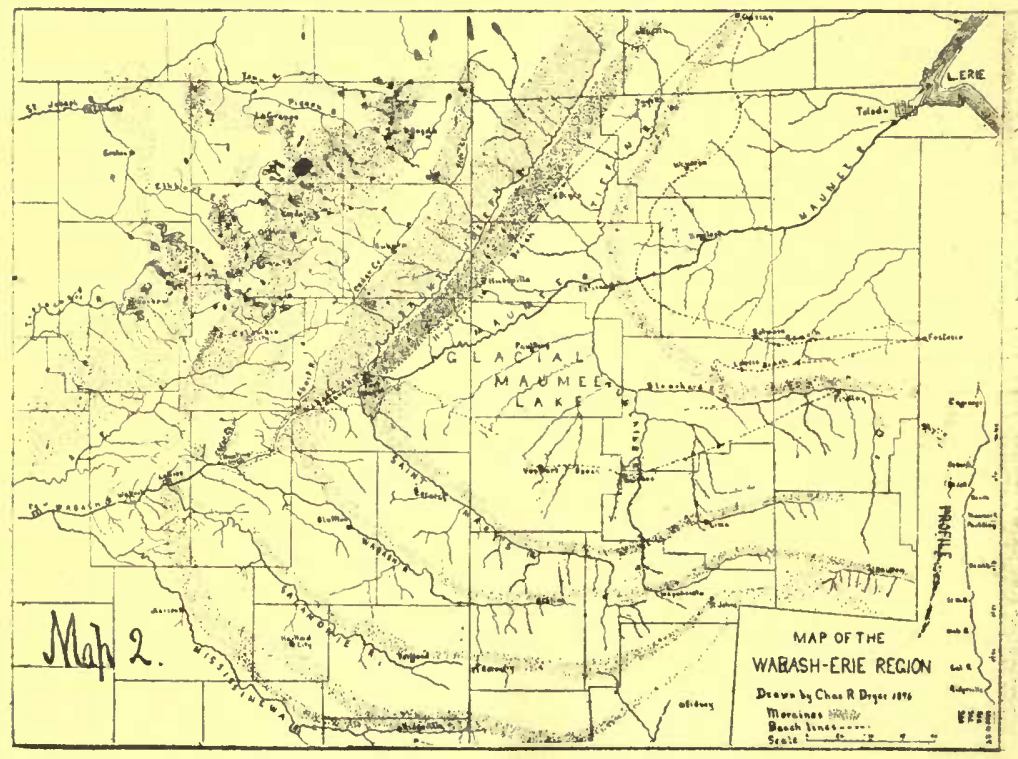

2. Glacial map showing moraines in whicb Lake Eagle and the city of Warsaw are located (Loaned by Prof. C. R. Dryer and Inland Pub. Co.) 
western end of Lake Erie, and which formerly at successive periods served to retain the waters of ancient Lake Erie or Lake Whittlessey on the south, and which for a time emptied its waters through the Ft. Wayne gap into the Wabash River.

The drift of the region is the regulation glacial till, such as has been observed and studied throughout the glaciated portions of the northern states. The soil content is largely made up of sand and gravel with a small percentage of clay material. The amount of clay or of the residues or any of the feldspars here, is extremely small when compared with that portion of the till of the states further north. In Wisconsin for example, and Illinois, the clay is often the chief constituent of the soil, but wherever found near the lake under discussion, it is of a light and soluble nature.

The surface is in general undulating, with here and there an abrupt knob and kettle area. These knobs are dome-shaped and the sides are frequently as steep as the material will lie.

The basin or kettle is the exact opposite of the knob, being formed into a deep rounded depression originaily by the melting of large masses of ice in the "till." These kettles are trom various causes filled with water and many of them become permanent lakes. Most of the lakes of northern Indiana owe their origin to these depressions in the morainic ridges:

There are several hill like elevations, probably eskers, scattered about the region standing usually at right angles to the strike of the drift. A particularly large one known as Chicago Hill, stands near the Biological Station at Winona. It is to all indications, a typical esker. It is composed of sand and gravel heterogeneously mixed. Its shape is high and oval but not lenticular and in these characteristics it is neither a kame nor a drumlin. This esker as well as all of the elevations of the region, has a vegetative covering varying in density according to conditions. As a rule, the slope to the south and southwest, owing to the exposure to the more direct heat in summer and consequent drouth, bears a type of vegetation approaching what is known among botanists as "Xerophytic." On the northern side of those hills however, owing to the in. creased shade and consequent addition of moisture, there is a transition from the xerophytic vegetation to that type known as "Mesophytic." As these and other ecological terms 
will be used more or less in this paper, it will be advisable to briefly explain their significance. In 1895 Warming, a European botanist, adopted these terms in his "Plant Geography." He divided the plants of the world into four great groups: Hydrophytes, or the plants which grow in water or wet places; Xerophytes, the plants which grow in dry habitats; Mesop. hytes, the plants which grow in places of medium moisture; such as ordinary forests and meadows; and Halophytes, or plants which grow in salt water or alkaline soil. Most botanists have accepted Warming's classification of plant societies as a more or less complete organization of this part of the physiographic-ecological field. The type of vegetation called mesophytic, requires protection from the cold and heat in excess, as well as good moisture conditions. The black and white oaks with an occasional hickory usually form the forest covering on the southern and western slopes. As one passes over the crest of these hills, however, a transition in the vegetative types is easily discernible. Descending the northern slope towards the bottom of Cherry Creek near the Biological Station, one first marks the elms. Following the elm comes the aspen. Then the sycamore comes in still lower. As one descends lower, the ash prevails. When the hill slope merges with the flood-plain, the walnut and red-bud are more predominant. Along the creek's margin, always depending upon the nature of the slope, the hazel, linden or basswood, and the willow (salix nigra) occupy. the space. The poplars occur here too, but irregularly. These trees furnish the observer with a direct clue to the topography: It is now well known that each particular topographic form has its own peculiar vegetation. To make direct use of the words of one of the foremost students and authors on the subject, "The reason that the type of vegetation is so closely related to the type of topography is that the soil conditions upon which the plants depend are determined by the surface geology and geography. From the standpoint of vegetation the topographic relations are more important than the geological. The topographic conditions determine the exposure, the presence or absence of drainage, and the humus content of the soil, and are thus of overshadowing importance. Having related the vegetation largely to the topography, we must recognize that topography 
changes, not in a haphazard manner, but according to well defined laws. In all the processes of erosion there is no more potent factor than that of vegetation. Regarding that many things may be cited. The peat deposits add greatly to the rapidity with which lakes and swamps are filled, while the plant covering of the hills on the contrary, greatly retards the erosive processes. As a consequence of all these topographic changes the soils and slopes must change; so that the plant societies which are replaced in turn by others, are adapted to the new conditions." It will be at once seen that there are mutually powerful agencies at work in an area like this of pronounced topography and strong vegetative influences. The erosive influences are all but balanced by the constructive work of vegetation. Among the various types of elevations, the esker, then represents a unit both topographically and ecologically. It possesses on its surface trees and undergrowth ranging from xerophytes to mesophytes. Within 150 paces, crossing its crest transversely, one passes from the scrubby black oaks, representing the xerophytic side, to groups of lindens and walnuts representing the mesophytic side. With its elevation of sand and gravel the esker furnishes the necessary conditions of exposure and protection from the rigors of heat and cold and moisture, which determine the vegetative types of its surface. What is here true of the esker is true of other elevations provided that they are of the same soil. A clay hill will differ in its vegetation from one of sand or gravel. However, the topographic relations are more important than the geological, and hence one will observe that the change in vegetation is only a modification.

The vegetative influence on the entire topography is very: marked. Located in the belt of heavy rainfall, with an abun: dance of water in the ground from springs, and in the air from evaporation of the lake's surface, the entire ground surface, with the exception of certain elevations, is covered with a rich herbaceous vegetation and the hills with dense forests. Wherever interfered with the forests are not luxuriant but where primeval they are grand in their thickness and deep shade. One stretch of elevation on the 20 foot contour line. and back from the lake shore a half mile, proved a magnificent sight. The trees, nearly all mesophytes, were lordly monsters. 
of the primeval time, towering high above without a limb or shoot. Their bases were deeply covered with mosses and lichens indicating the extremely favorable conditions for vegetation. Thesr roots were spread over a great area and owing to the wet condition of the ground, they were trched into "knees." The shade of this forest was so dense that only such plants as ferns could prosper. There were many varieties of these and their long and beautiful fronds grew in heavy clusters. A wagon road had been opened up through one part and here the Impatiens, nettle, and the Pilea had made haste to get rooted in the rich humus. On the edges of this road the hazel and the red bud had become established. This was a beach-maple torest and these facts illustrate how completely shaded a mesophytic forest's soil is and also how largely all chances of developing undergrowih is shut out from it.

There is no doubt but that a generation ago there existed here the densest and heaviest of woods. Old settlers say that even 50 years ago they were able to take out logs and timbers which for size and value rivaled the best of the Michigan forests. The natural undergrowth is so heavy in the open that all lines of drainage are clogged and continually threatened with destruction. In some cases these lines have been artificially reopened but only to again suffer destruction by vegetative obliteration. Lilies, rushes, cat-tails, and zone upon zone of brush and shrub close in on the lake and continually narrowits confines from the sides and raise its bottom by heaps of debris of the dead plants. One would naturally ex-

- pect that at the outlet of the lake there would be some or even considerable erosion at the present time but there is none that is perceptible. It is a case of a stream that has found its valley, not made it. The outlet stream meanders along slowly through dense masses of aquatic and semi-aquatic vegetation, on a slope of exceedingly small gradient, untila point far below the upper dam is reached. Here the erosion setting in from the Tippecanoe is asserting itself and the gradient increases very rapidly. It seems that the ordinary course of nature viz; cutting down by erosion and destruction of water bodies by the ascending heads of tributary streams, is here reversed, and that instead, we have forces acting in the opposite manner. Thislake, as far as its water body is concerned, 
would probably remain for thousands of years, vegetation preserving it from any tendency toward destruction by drainage and until the ascending line from the Tippecanoe would reach the lake's margin. This point is now located between $A$ and and $B$ on map $I$. At this point erosion is active.

The lake itself presents a rare place for the aquatic plants to perfect their types. The perfection of types, however, and the enormous multiplicity of numbers means, sooner or later, death to the lake itself. The shores low and marshy, also present the most favorable surroundings for the furtherence of vegetative growth. Great beds of Scirpus skirt these shores and extend far into the lake. Thick beds of Chara and pondweed (Potamogeton) are closer in shore. In intervening places on the marshy shores extensive beds of the pond-lilly (Nuphar) with their heavy, soggy stalks and enormous spread of leaves are aiding the other types in raising the lake's bottom with the detoris of the dead and dying plants. Back of the immediate margin of the lake but still in very wet soil, are beds of cattail growing luxuriantly and beyond these the heavy swamp grasses are established. Then the vegetation increases in height and size and thick zones of brush intervene between the lake and the first line of trees. Among the more plentiful varieties of the trees associated with the lake and its life history, is the willow and particularly, the Salix nigra. Wherever one may go about the lake's vicinity, these black willows are always in evidence. From the fact that most of them are now in full maturity, their existence there seems to point to a time when conditions differed essentially from the present. Many of them are dying which also points to a changing environment. They stand for the most part in continuous lines or zones and suggest the pre-existence of water lines. They are in their youth, associated with running or quiet water so that now one can say, since they are in full maturity and farfrom any water, that they once marked the edge of the lake. This inference comes from observation of the the habit of the tree and its love for water, for when the spring comes and the young shoots appear, along the water's edge a long line of willow shoots are seen beyond where any other plant has ventured. The seeds of other plants have gone as far perhaps, but could not endure the 
conditions and the place has fallen to the willow. Hence it is now generally recognized that a line of willows in natural surroundings; indicates a former water line even though there is no beach-line in evidence.

Extending through the mesophytic forests on the low ground about the lake and especially upon the southern and eastern sides, are numerous lines, in some cases double. These lines are those made by willow trees. Between these lines of trees there is an intervening space of about twenty-five feet. The lines are made up of fully matured Salix nigra. These lines are so peculiarly continuous that they seem to indicate the former margin of drainage channels. These linesrepresenting tributaries, have in the last century, occupied many different channels. The streams have wandered at will over old lake bottoms, whence the lake water has receded, so that they represent typical flood-plains. It is on these primitive flood-plains that Salix nigra grows in such continuous lines, suggesting the history, at least in part, of the creek and lake. In one small area especially studied, six different oscillations of the channel were observed. In some cases the evidence of ecology was corroborated by the still lingering depressions or extinct channels in the ground.

\section{THE ANCIENT LAKE}

About one-fourth mile to the east of Chicago and Hamilton Hills, the two eskers mentioned near the Biological station, one comes suddenly upon a' large and continuous embayment. It is now dry having no water connection with the lake. Formerly it was filled with an arm of the old lake. Now it has the appearance of a deep and wide valley. Hidden from view by heavy forest growth, the valley appears as a case of past erosion at a time when an enormous amount of water went through it. It is impossible to suppose that the present feeble stream which meanders through the deepest parts was ever competent to perform any such amount of erosive work. It seems like placing the Tippecanoe River in the valley of the Mississippi and making it responsible for the valley. The idea, then, that this great embayment was the result of erosion, is clearly unsatisfactory. Neither is it prob. able that the valley is one formed by river erosion but one evi- 


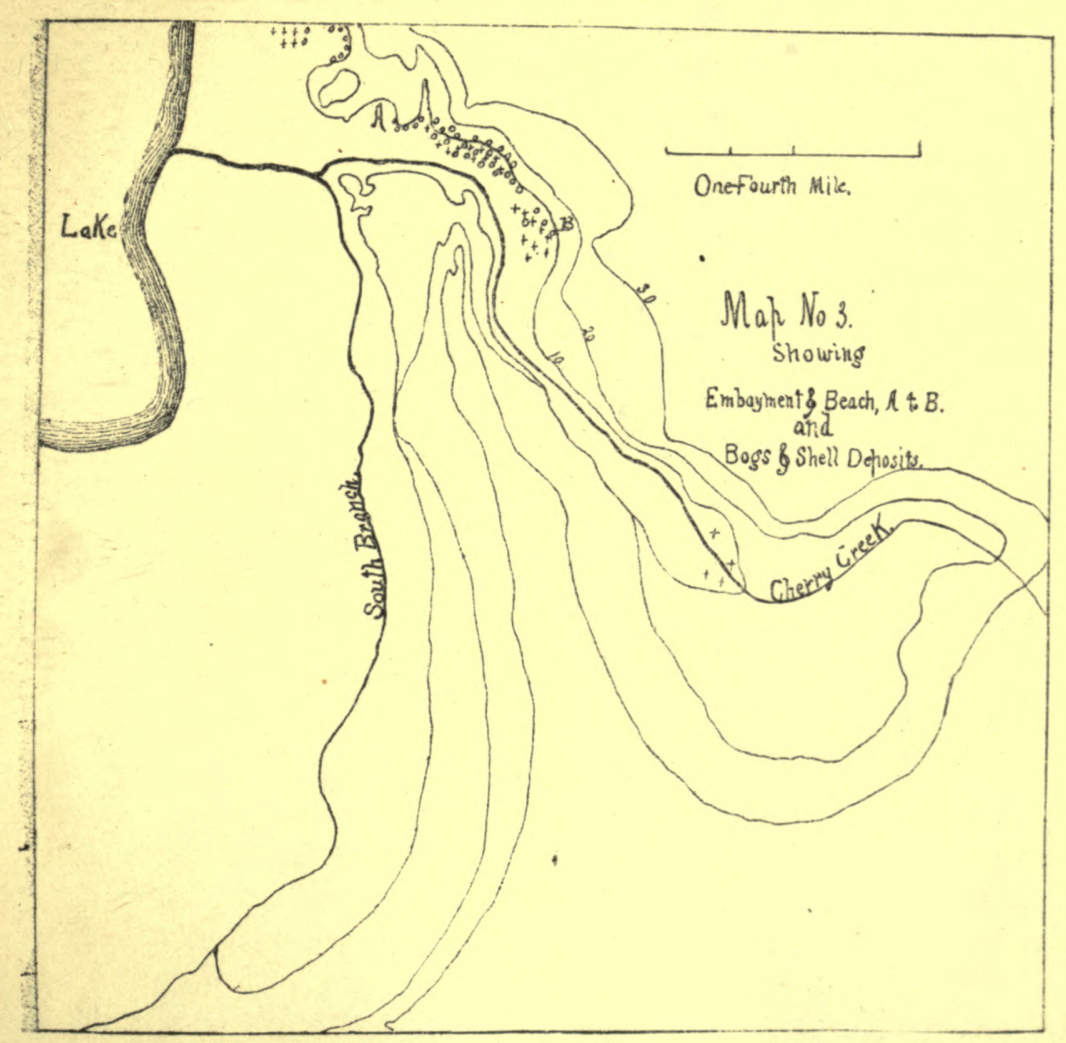

3. Map of "The Embayment" and the Cherry Creek Valley. 

$\because$ 


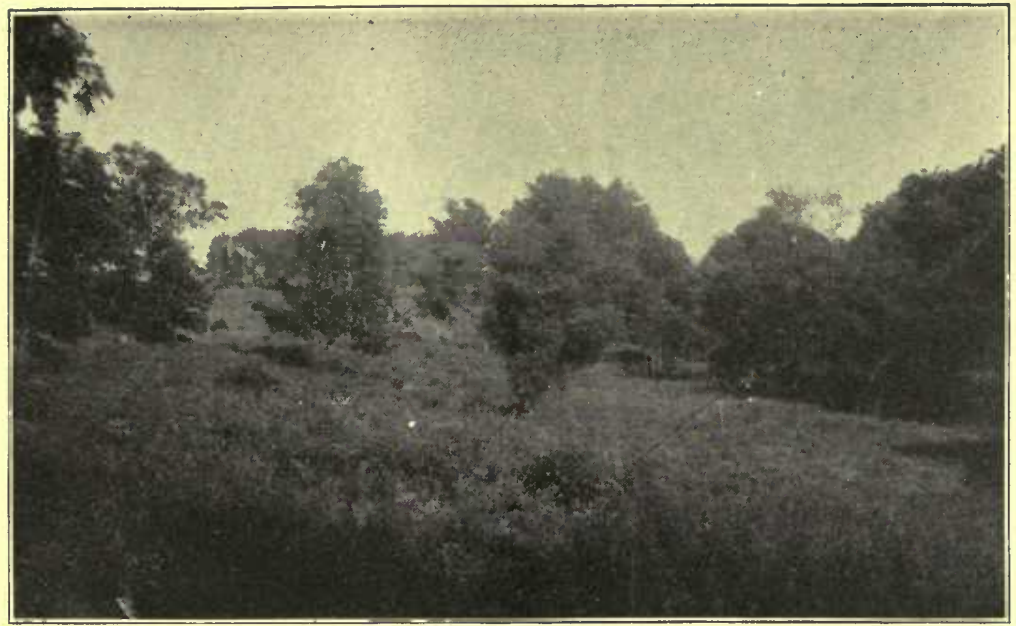

Fig." 3. A view looking lengthwise E. \& W. of the "embayment" discussed in the text. In the extreme right winds the main branch of Cherry Creek while on the left may be seen the higher points of the la. custrine beach. The vegetation, both of the trees and the undergrowth, is very characteristic of such a slope. The trees vary from the black and white oaks on the left to poplars, sycamores, and elms in the centre and the black willow (salix nigra) on the right. In the left foreground are the bogs mentioned, in which the biological remains are so well preserved.

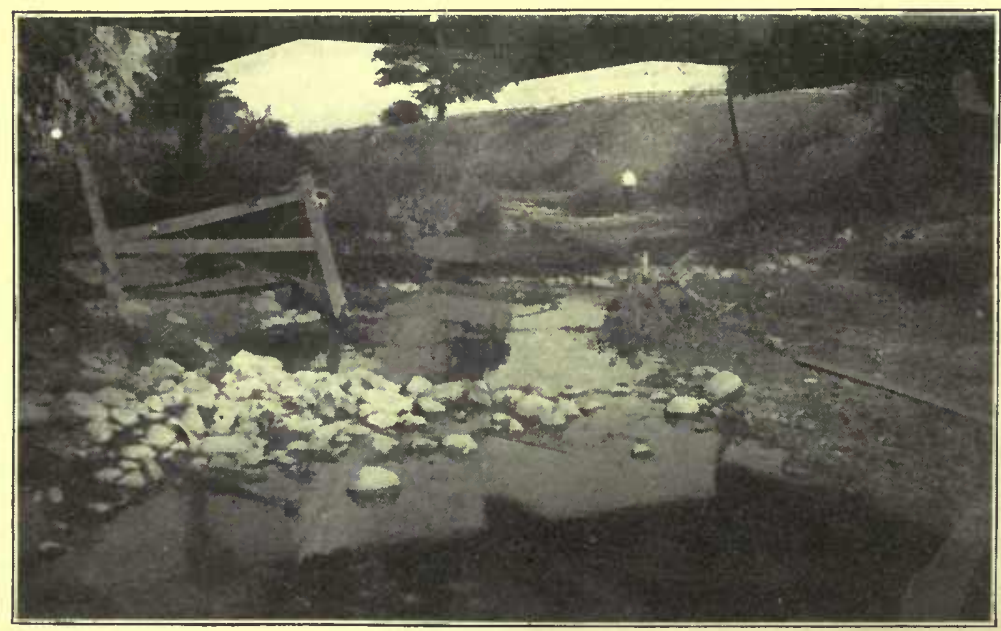

FIG. 4. View at the point of greatest gradient and erosion in the head waters of the Tippecanoe where the stream has all but succeeded in tapping Eagle Lake. The lake is less than a half mile distant. The view also looks diagonally across the site of the greater dam to the southern abutment. This is $\mathbf{2 2}$ foet high, at the base of the large white oak in the back. The stones in tha foregruand are $\mathrm{m}$ ss:ly limestones of the till. 
dently formed by three forces. First, the shape of the topography as left by the giacial ice; second, the erosion which has gone on both with the creek's aid and by side wash; third, the effect of lacustrine action and forces which have been long at work and have accomplished much as will be evident later.

In observing the contour map it will be seen that this enbayment formerly stood at the lake's edge, but the lake has since evidently receded. As one ascends the depression to the eastward, (this depression is 500 feet wide, and more than 2,000 feet long to its southward turn), he will observe upon the left hand a broad sloping beach extending eastward to the turn mentioned. Its base begins in a line eight feet above the present lake level, and gently and evenly ascends to a height of eighteen feet above the lake. It is decidedly lacustrine in shape and formation and can in no way be laid to river terrace work. Across the valley southward no beach exists, the peculiarity of the formation being that the beach is found only on the northern side. This beach occupies a space between $A$ and $B$ on map 3. It will be seen that this beach, supposing that the lake levels stood as indicated on the contour map, marks the place that would be subject to the strongest wind and wave action. The prevailing winds of this locality being those of the same latitude, viz; southwest, and there being an expanse of water surface some two miles long, it will be seen how easily this beach might be developed. Remove the present intervening mesophytic forest existing between this point and the lake's margin; raise the lake level over 20 feet, and one can readily imagine what the situation might be and what the opportunities for the development of such a beach were, The ecological factor in proving up the beach is close at hand.

A line of Salix nigra of full maturity skirts the lower edge of the beach clearly indicating the former reach of water and of willows, about eight in number, is plain and sharp in outlines, representing a gentle concave curve toward the present channel. At the bases of these trees there is a, somewhat sharp declivity of about three feet indicating that while the level of the water stood here, the outlet, for some reason, was suddenly lowered. For the reason that the exact age of these 
willow trees was not ascertained at the time of the writer's visit here, and no safe comparison can be now ventured between the ages of these and other old trees lower and nearer the lake, it is perhaps better to offer this last evidence with this note. It seems that the line of Salix nigra spoken of indicates the former margin of the lake shore. Whether this is from the fact that water was formerly here and this is what appears to be so, or whether the trees in their growth took advantage of the shape and slope of the declivity is not positive. It is better to use the evidence as corroborative perhaps, to take the evidence of the line of willows with that of the exis. tence of the beach and the deposits of the bivalve shells. The strongest evidence on the point would not be the ecological, nor the geological but the zoological. When once the two latter have been accepted, it is easy to see the place and force of the ecological evidence. Back of this beach formation, the surface rises rapidly and abruptly twenty.four feet above the lake level. Beyond this higher altitudes obtain until heights of fifty and sixty feet are marked by the aneroid.

On a level with the beach and on the northern side of nearly the whole length of the embayment, which is between 7500 and 10000 feet long, are numerous springs and peat bogs. These springs and bogs are perhaps among the most remarkable things to be noted in the locality, for from their peculiar nature emanate many other phenomena such as the preservation of old lacustrine biological remains and the cementation by their calcareous waters of the glacial sand and pebbles of the bog's vicinity into a conglomeratic mass. This is of course a post.glaclal conglomerate. The spring waters, nearly always associated with the bogs, issue from the ground cold and heavily charged with calcareous salts in solution, which, upon the evaporation of the water, succeeded in cementing the pebbles and sand particles, among which the water was filtered, into the conglomerate. These masses of cemented rock are found quite plentifully here on the gully slopes and in great hill side masses at Wabash. For illustration of this see Fig 8. These spring waters on entering the lake, have their temperature effectually raised so that any body with which 
they happen to conse in contact becomes entrusted with limy scales. The plants of the lake in particular, are acted upon in this manner and are materially increased in weight and bulk, thereby augmenting the vegetative and mineral deposits upon the lake bottoni.

Upon a level with this beach and on the northern side of this embayment are located many deposits of shells and vegetable remains. These deposits are in the bogs before mentioned. The nature of the soil of the bog is such that it will preserve from oxidation and destruction any fossil remains either of vegetative or animal nature and especially important for the point at hand, calcareous shells. These shells are those of lacustrine life, hence in these bogs may be found well preserved relics of past years which aid in the interpretation of the natural history of the region. Apart from these bogs the soil has not aided in protecting these plant and animal remains from total destruction either by oxidation or by the root acids in the soil. It is practically a waste of time to search through sandy soil or through soil much exposed to the forces of weathering for remains such as are spoken of for the reason that they will be entirely consumed in oxidation. In these bogs are large deposits of univalve and bivalve shells. The univalves, although plentiful, do not necessarily give evidence of lake life for it is well known that they frequent both the waters of lakes and springs. The existerice of the univalves in the bogs alone and separate fromany other evidence, furnishes only valueless and unconvincing proof for the bogs are or have been associated with the springs, but the occurrence of the bivalve shells with them renders the conclusion more certain. The bivalves are, on the other hand, never found apart from lake-life and therefore never in springs, so that the existence of the lake level formerly at this point is demonstrated. It is proven in three ways. First, geologically, by the detailed account of the probable formation of the beach mentioned; second, botanically, by the zones of Salix nigra, willows lining the beach after their habit and life history is recognized; third, zoologically, by the numerous depusits of shell life in the bogs now existing on a level with the beach and in the close proximity thereto. This one case of verifying scientific 
theories in the field certainly convinces one of the extreme value of associating the sciences together especially where they are so closely related as Physiography and Ecology. When a small knowledge of one is once gained it is next to impossible to rely alone upon the other. Dr. H. C. Cowles of the University of Chicago, made a visit with the writer to the localities mentioned and it was apparent that the formations and deposits were due entirely to lacustrine action and that the further evidence necessary to establish the fact that the ancient lake stood at these altitudes and was instrumental in the creation of the evidence cited, was, after demonstrating the existence of a IO and 20 foot contour line around the lake. to locate if possible, a dam or the remnant of one at the outlet.

- The contour lines of Io 20 , and 30 feet are not altogether continuous in the vicinity of the lake especially on the nor. thern shore. While the surface rises to higher altitudes east of the lake, on the south and west the surface is so effectually broken up by embayments that it is with difficulty that the contour can be traced. Those east and south of the lake are, however, fairly continuous. The Io foot line is followed with but little difficulty but the 20 foot line takes in such a vastly greater area that it is necessary to make constant reference to the level and aneroid to establish it. There is no doubt that the 30 foot line would include not only most of the city of Warsaw, but even Centre aud Pike lakes. On the west the high grounds close in rapidly upon the lake and since this side is free from tributaries, there are practically no embayments. Of course at the outlet there is a depression leading toward the Tippecanoe River. This depression as far westward as the letter B on map I, was filled with water when this lake was at its maximum height. This embayment varies greatly in width and is about one and a half mile long. For most of the distance the ro foot contour line runs close to the channel, the 20 foot line setting back considerably. All of the contours converge at $\mathrm{B}$ which was found to be the location of the greaterdam. At A five eights of a mile east and where the Io foot lines are seen to converge, was found the location of the lesser dam. These two dams contained the ancient lake waters. 
$\because$

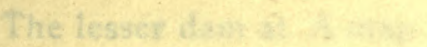

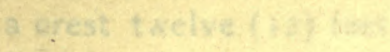

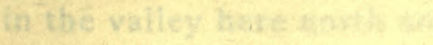

cowerge percepitibet ment m

twatly athand tothest

ech side, reaching

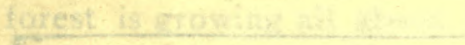

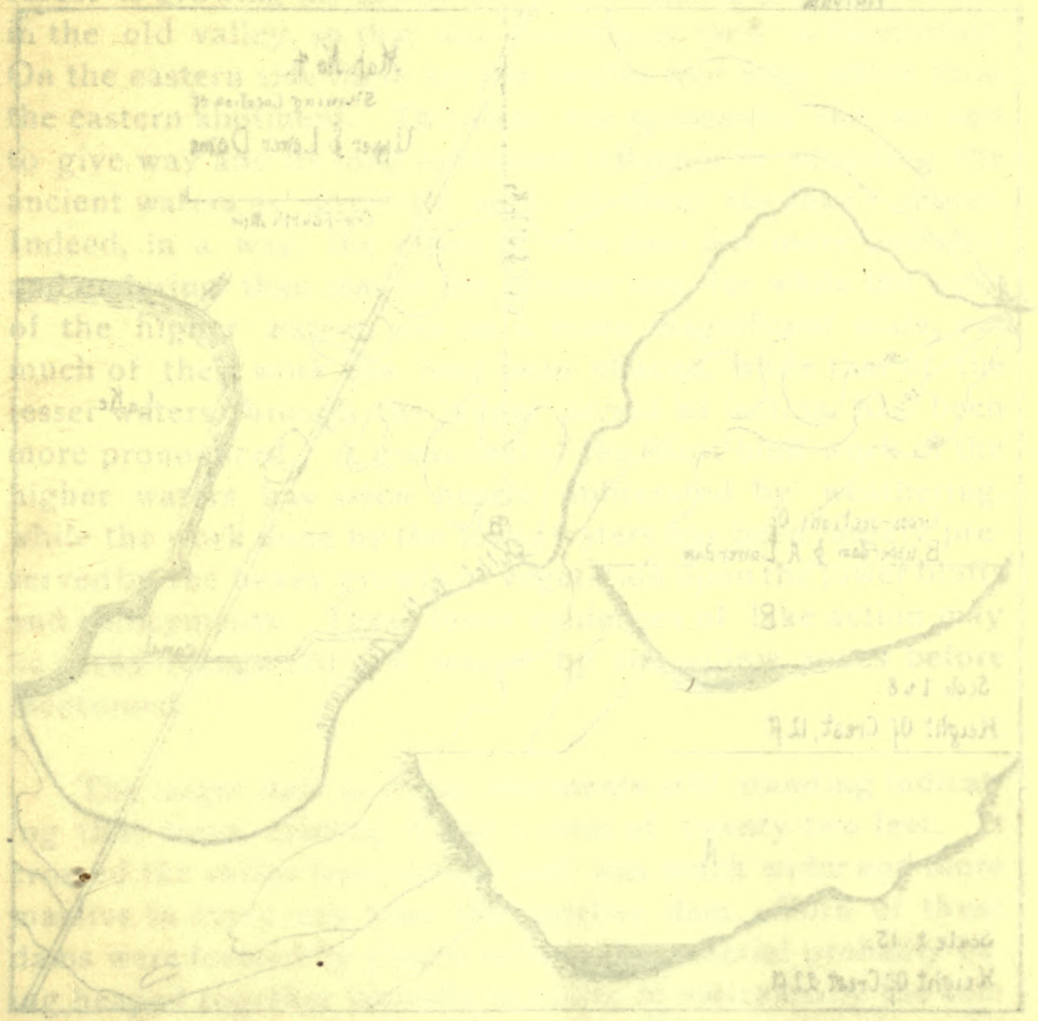

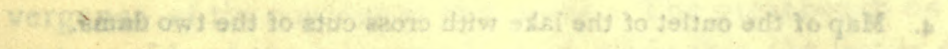

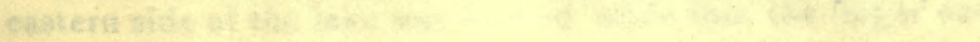
whes lotace.

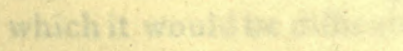

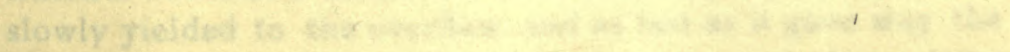

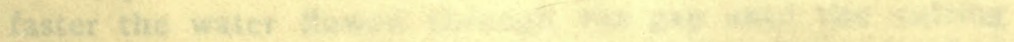

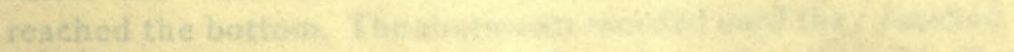

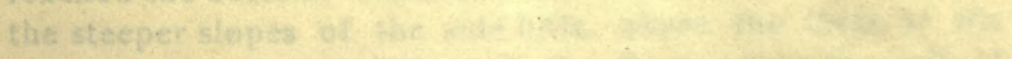

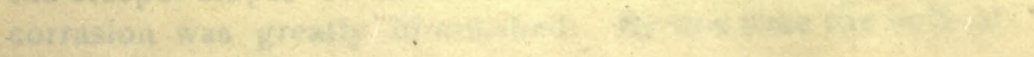




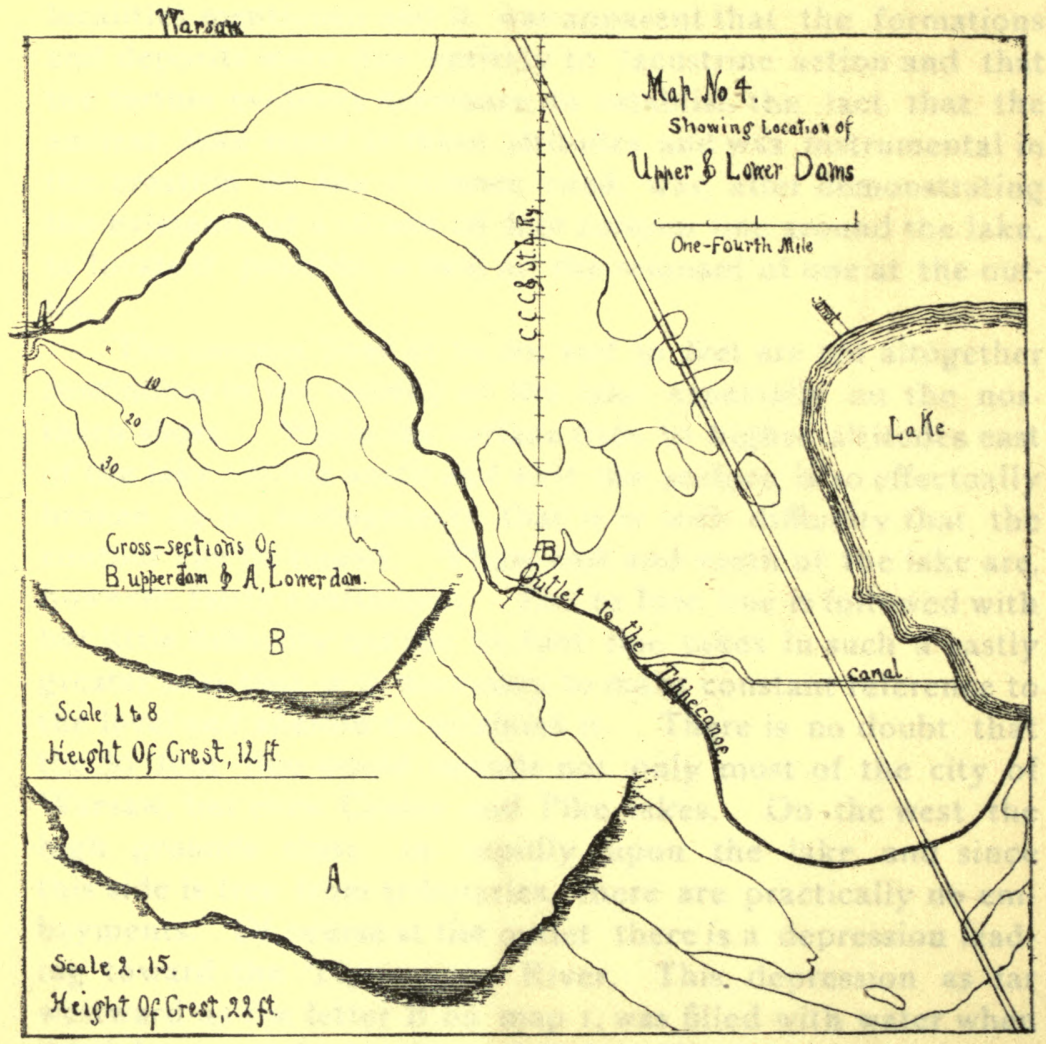

4. Map of the outlet of the lake with cross cuts of the two dams. 
The lesser dam at A map I, if it now existed, would have a crest twelve (12) feet above the lake waters, and would fill in the valley here north and south. The three contour lines converge perceptibly here on the west, but only the ro foot is actually at hand. The altitudes go above it however on the western side, reaching nearly eighteen feet. A heavy mesophytic forest is growing all about the place both on the heights and in the old valley, so that any continuous view is impossible. On the eastern side there are two twelve foot hills which form the eastern abutment. This dam was apparently the last one to give way and its long continued influence in retarding the ancient waters is distinctly seen all about the lake's shores. Indeed, in a way, the effect of this dam was more powerful and enduring than that of the greater one, for while the work of the higher waters was on a more magnificent scale, yet much of their work has long been effaced, while that of the lesser waters through the longer period of action, has been more pronounced. A great deal of the finest bluff work of the higher waters has been nearly obliterated by weathering. while the work done by the lower waters has been largely preserved by the heavy growth of vegetation upon the lower bluffs and embayments. These lower evidences of lake action may be easily recognized and traced by the willow zones before mentioned.

The larger dam at $B$ has abutments still standing indicat. ing that when existing it had a crest of twenty-two feet. It crossed the valley transversely and was much wider and more massive in every way than the smaller dam. Both of these dams were formed by glacial action, the material probably being heaped together laterally in ridges as indicated by the convergence of the contour at this point. The greatbeach on the eastern side of the lake was formed while this, the larger dam was intact. After a length of time had elapsed, the length of which it would be difficult to measure, the upper part of the dam slowly yielded to the overflow, and as fast as it gave way the faster the water flowed through the gap until the cutting reached the bottom. The abutments receded until they reached the steeper slopes of the side hills, where the force of the corrasion was greatly diminished. By this time the bulk of 
the water of the ancient lake had passed on its way and had reached the Tippecanoe, a mile further to the west. It was at this time and not until then, that the overflow began on the small dam. The time necessary to destroy this one, although much smaller and retaining a vastly smaller basin of water, must have been very long, even vast, to permit the work that was accomplished by the waves of that long period. When we think of the almost even conflict that is now going on between erosive and constructive forces with the ever deepening drainage lines on one hand and their continued tendency to become obliterated by vegetation, on the other, and the many years needed to show progress on either hand, some conception may be had of the lapse of time between the accumulation of the lake body and the final outflow through the eroded dam. It is interesting to think that the erosion lines seen now ascending the outlet from the Tippecanoe (See figure 4 of the report), would have crept up the gradient from the river, and succeeded in tapping the lake at the greater dam whether the crest had yielded to the force of the overflow wear or not. However, it would yet take many years for this danger point spoken of to reach the dam and begin its work. The soil of these dams is of course the same existing in the other parts of the morainic uplands of the locality, sand and small gravel being the chief constituents. The measurements and other items of the dams as well as two maps of the same, may be seen in other parts of the report.

THF: LAKE SHORES

The vegetation of the lake and that of its shores is materiially effected by the nature of the soil of its bed and margin. The soil at any point is determined by forces and factors in constant operation, chief among which is the proximity to elevated lands. The erosive forces of this area are powerful, both by reason of the rainfalls which are heavy and the nature of the soil which is such as to be quickly affected by water. The amount of detritus removed from the top and side of a hill during the season of heavy rains is enormous, especially when these points are denuded of forests and under-vegetative growth. It is not uncommon to see deep gullies, running to 


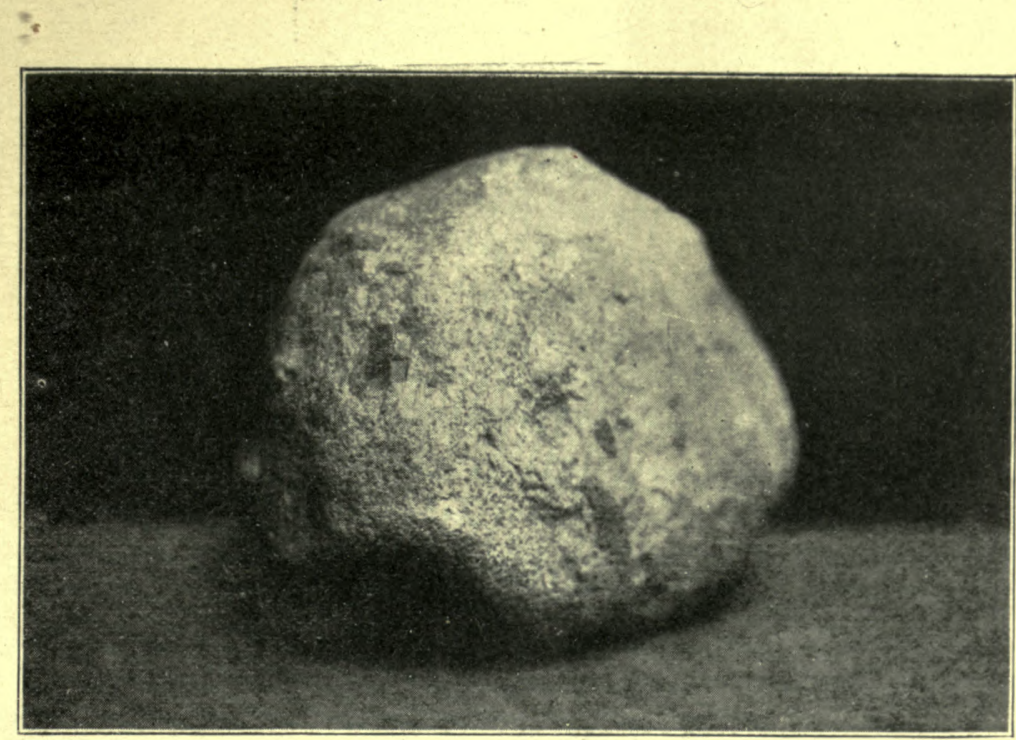

FIG. 5. Sample of Jasper conglomerate found plentifully on the surface around the lake. The specimen is eight inches in diameter.

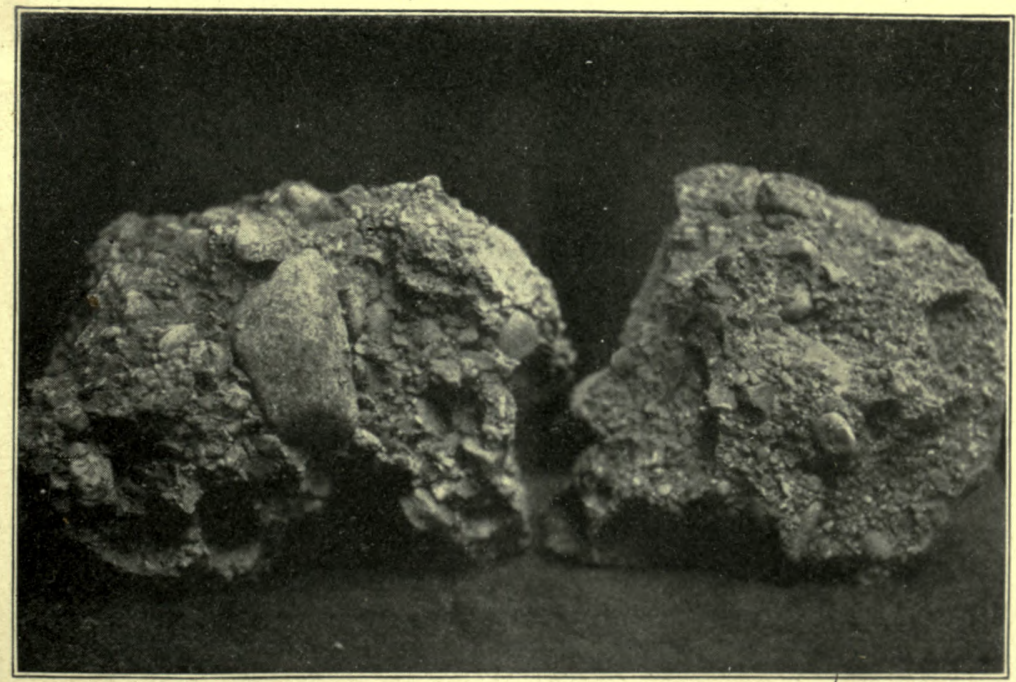

Fig. 6 Samples of the post-glacial conglonerate found near the mineral springs in Cherry Creek embayment and in large masses at Wabash. The glacial pebbles are resting in a matrix of ordinary sand, the whole cemented by the calcareous water of the springs. It is not easily fractured. The above is now in the ge slogical collection of the Field Museum where it is unique in being the only evidence of a calcaresus conglomerate formed by calcareous springs. 

the base of a hill, after a severe rainfall, their whole course lined with deep potholes formed by the rush of water and the whirl of the till boulders. The load of detritus spread in a huge alluvial fan at its base, will in many cases measure twenty cubic yards. When the hill slopes to the lake shore, this eroded material, it will be seen, determines the soil content of the beach, especially where there is no intervention of bottom or inarsh. The small amount of clay in the till, owing to its very light nature, is carried away in suspension.

It has been suggested that the stretches of sandy beach of to-day might be accounted for by the combined torces of wind and wave action, grinding up the glacial pebbles and spreading out the accumulation to form the beach. The occurrence of some of these sand beaches on the north-eastern shores, where the south-west winds for most of the year spend their force, might seem to partially corroborate this, but surely a second thought would dispel it. In the first place no glacial pebbles (quartz pebbles) are exposed to the action of the waves, the accumulation of peat and marl completely covering so heavy and immovable thing as a pebble. The light shifting sands consequent on the side-wash and erosion of the adjacent hills keep the marl and peat deposits well under cover in their immediateneighborhood. In the second case, long stretches of sand beach occur on the southern and eastern shores, where the prevailing winds do not cause the waves to beat. There has been someconfusion in passing judgment on this point. A "beach on this lake, and the 'other lakes of the neighborhood, is either sand or marl, and it should be easy to determine which. It should be easy to distinguish between a beach made up of fragments and particles of shell-life which is largely calcium carbonate and one made up of sand and gravel mainly the oxide of silica. It is clear then, that the origin of these sand beaches is connected with their closeness to the sand and gravel hills and ridges, the change in place being effected by erosion and side-wash, and not in grinding and piling up by wave and wind action of glacial pebbles.' A casual inspection of the map of contours should show this.

The stretches of marl beach are in part one of the present enigmas to be cleared. They seem, on close inspection, to 
consist of particles and fragments of shells from mussels down to univalves. However, when the extreme depth of these marl deposits and beaches, which ranges from two to twenty feet, and the size of the lake together with its life capacity is considered, there certainly seems to be a discrepancy in comparisons. Probably all of the deposit is not made up of mineral calcareous matter from the springs, or of animal calcareous matter, but in addition to both of these there is a third element, viz.; the remains of lake vegetation which formerly was, while growing, encrusted with a limy covering. Nothing aside from close chemical examination would satısfactorily determine the solution to the question, whether these extensive deposits depend upon the mineral deposits of the springs upon the remains of shells, or upon the lacustrine vegetation. The deposits must have covered an area commensurate with that of the ancient lake for at points some distance from the present lake margin, marl deposits have been found with evidence indicating that they were continuous with those of the present lake. At several points about the lake, canals have been dug, and in all instances deep beds of marl have been unearthed. There is above this bed a thick solid layer of peat about a foot and a half in thickness. It would be interesting to compare a chemical analysis of this ancient marl, so old as to have a dry solid bed of peat covering eighteen inches, with one of the present time.

There is in the area here a dearth of the boulders generally seen in the till of glaciater countries. Those that are here are small and do not at all compare with the great masses of them either in Michigan or Wisconsin. Neither do they compare in the variety seen in the fields mentioned. A part of this dearth is due no doubt, to the greater distance from the original location of the rock outcropping, many being dropped by the way. Again the reduction in size was probably affected by the increased allotment of time in transit which means of course, continuance of the grinding process by the ice. The prevailing boulder is dolomite. Then comes the granite, usually very numerous and large in glaciated countries but here very small. Diabases are few and also quite small. Some Jasper conglomerates are to be found scattered on the till surface. One of these appears in one of the figures of the report. 


